\title{
Sex differences in the activity wheel and open field as a function of fetal $x$-irradiation ${ }^{1}$
}

\author{
JOAN C. MARTIN ${ }^{2}$ \\ DUKE MEDICAL CENTER
}

Female rats fetally irradiated on gestation days 19 and 21 make significantly more turns in the wheel than comparable males. The activity pattern as a function of dose level was similar for all 21 day Ss. This was not true of the 19 day Ss. Fewer squares in the open field were entered by females as a function of dose received. The reverse was true of males.

Although the covariation of structural, morphological, and physiological changes with fetal irradiation has been well documented in rodents (Hicks, 1953; Russell, 1954), the concomitant behaviors have not been as thoroughly studied. For example, it has long been known (Hitchcock, 1925) that adult female rats are twice as active as males due to hormonal changes during the estrus cycle.

Irradiation studies which have investigated activity have virtually ignored sex as an independent parameter. Furchtgott \& Echols (1958) held sex constant by testing fetally irradiated rats prior to maturity. Manosevitz \& Rostkowski (1966) found neonatally irradiated female mice to be more active than males. The literature has not revealed a similar study with fetally irradiated Ss.

The following two experiments were an attempt to determine if fetal irradiation during the last trimester of pregnancy had a differential effect upon male and female Ss. The number of turns in the activity wheel and the number of squares traversed during the first $10 \mathrm{~min}$ in the open field were the measures used.

Apparafus

A standard Wahmann activity wheel was connected to a Foringer counter. An $8 \mathrm{ft}$ sq open fleld, illuminated by fluorescent light strips positioned above it, was painted silver and divided into 64 squares.

Pregnancies

A male was placed with six to eight females of Osburn Mendel ancestry and removed an hour later. Vaginas were checked the following morning for the presence of sperm. Two gravid females were randomly assigned to each treatment condition and on either Day 19 or 21 of gestation were transported in individual cages to the X-ray room.

\section{Imadiation}

A Picker $120 \mathrm{kV}, 15 \mathrm{~mA}$ machine with $2.0 \mathrm{~mm} \mathrm{Al}$ added filtration was the source of irradiation. The settings were at $103 \mathrm{kV}, 5 \mathrm{~mA}$, with a target to object distance of $18 \mathrm{in}$. The animals received $10 \mathrm{R} / \mathrm{min}$ for a total dose during the single Irradiation period of either 0,150 , or $300 \mathrm{R}$. The $0 \mathrm{R}$ group was placed in the $X$-ray room for a comparable period but the machine was not activated.

Offspring

These were weaned at 21 days and assigned four to a cage according to sex and dose. There were four males and four females at each irradiation level in the 21 day group. Due to deaths the same division was not possible for the 19 day group except for the $150 \mathrm{R}$ rats. The $300 \mathrm{R}$ group had three females and no males. There was one control, or $0 \mathbf{R}$ group, which had four of each sex and was sham irradiated on Day 21. Procedure

At 60 days of age the Ss were placed in the activity wheel for $15 \mathrm{~min} /$ day for five days. On the sixth day the Ss were transported to another building and placed in a corner of the open field for $10 \mathrm{~min}$. A tally was taken of the number of boli deposited. Inner square counts were also taken but discarded, since only five Ss entered an inner square.

Resulis

21 day $S s$. Two 3 by 2 analyses of variance with four replications were performed on the data (Winer, 1962). The activity wheel measure yielded $F=8.60$ ( $d f=2 / 18, p<.01$ ) for the Irradiation component. The Sex factor was significant $(F=6.12, d f=1 / 18, p<.05)$. The Irradiation by Sex interaction failed to reach significance (see Fig. 1).

Open Field. Irradiation, Sex, and Irradiation by Sex were all significant at $p<.01 \quad(F=9.26$, df $=2 / 18 ; F$ $=8.42, \mathrm{df}=1 / 18 ;$ and $\mathrm{F}=13.87, \mathrm{df}=2 / 18$, respectively; see Fig. 2).

19 day $S$ s. Two 3 by 2 analyses for unequal cells were performed by the North Carolina State Computing Center. Only the interaction effects were tested. Activity wheel scores yielded an $F=4.71$ (df $=1 / 18$, $\mathrm{p}<.05$; see Fig. 1). The open field data yielded an $F=9.13(d f=1 / 18, p<.01$; see Fig. 2).

Discussion

The 21 day males and females both exhibited an inverted $U$ shaped function over treatment levels on the activity wheel. The females were more active at all doses. Radiation increased activity at the lower dose for both sexes and, at the higher dose, both dropped to control levels or below.

Fetal irradiation on Day 19 differentially affected males and females. The activity level was positively correlated with dose for the females. In this respect the results resemble those of Furchtgott and Echols, who found that rats irradiated on Day 18 were more 
active than controls at the $300 \mathrm{R}$ level. Sex differences there were not apparent since the Ss were tested prior to maturity.

The $150 \mathrm{R}$ males in the present study were no more active than controls. There were no male survivors at the $300 \mathrm{R}$ level. However, a $200 \mathrm{R}$ group which inadvertently received a fractional dose, and was excluded from the analysis, did exhibit a marked increase in activity over the $150 \mathrm{R}$ rats. No male group was as active as any female group.

The number of squares entered for both groups of females was a monotonically decreasing function of the amount of irradiation received. The control and $150 \mathrm{R}$ females entered more squares than did the corresponding males.

The 19 day $150 \mathrm{R}$ males did not differ from control males, and the $200 \mathrm{R}$ group (not included for reasons cited above) entered even fewer squares. The reason for the increased activity of the $300 \mathrm{R}, 21$ day males is not apparent. This was the only male group in both studies which was more active than a female group. The higher level of irradiation on Day 21 apparently had a differential effect in terms of sex.

Defecation. Although other investigators have used defecation as a measure of nonhabituation (Broadhurst, 1957; Furchtgott \& Echols, 1958), it was useless in the present study since few Ss defecated at all. There

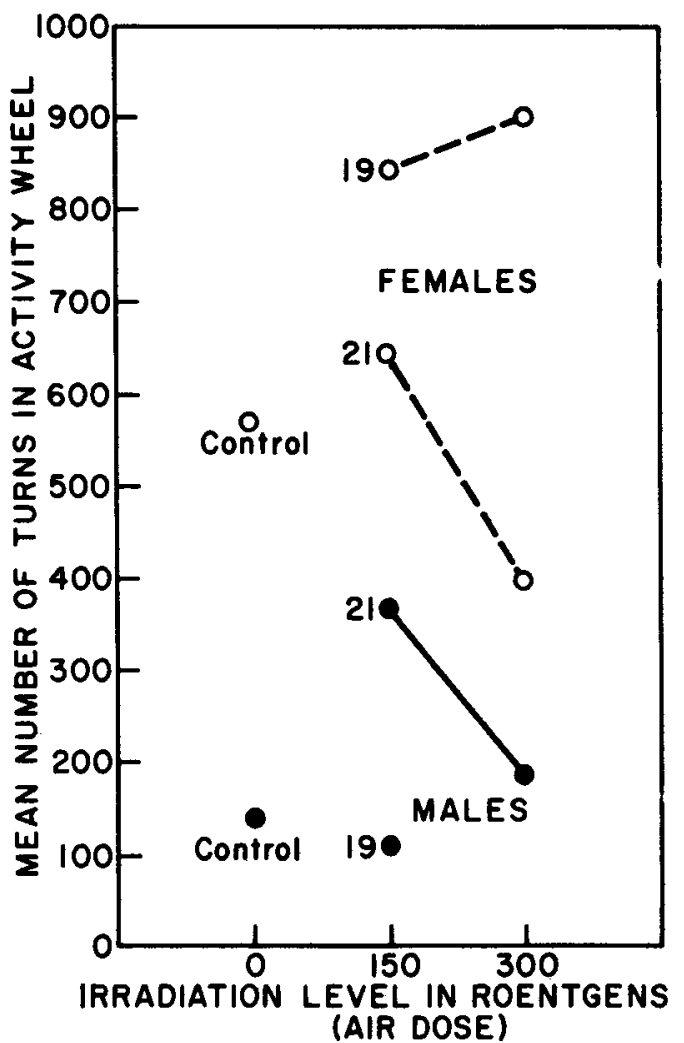

Fig. 1. Mean number of turns in the activity wheel over five trials as a function of irradiation level.

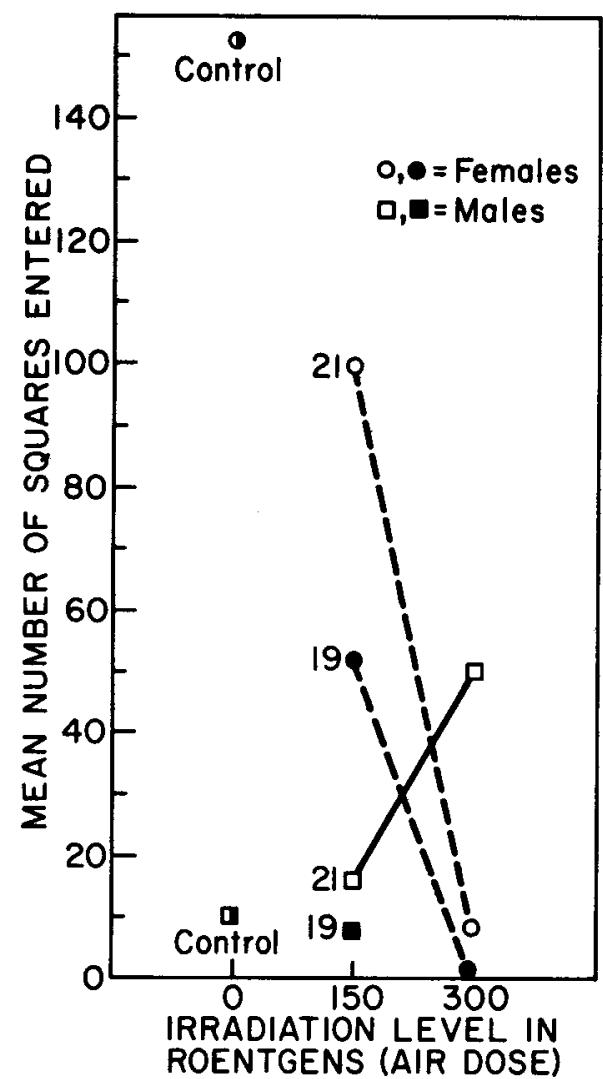

Fig. 2. Mean number of squares entered during the first $10 \mathrm{~min}$ in the open field as a function of irradiation level.

was a nonsignificant tendency for the 19 day group to defecate more than the 21 day group or control Ss. No sex differences were noted.

Further studies should clarify some of the puzzling relationships in evidence here.

References

BROADHURST, P. L. Determinants of emotionality in the rat. I. Situational factors, Brit. J. Psychol, 1957, 48, 1-12.

FURCHTGOTT, E., \& ECHOLS, M. Activity and emotionality in pre- and neonatally $\mathrm{X}$-irradiated rats. J. comp. physiol. Psychol, $1958,51,541-545$.

HICKS, S. P. Developmental malformations produced by radiation. A time table of their development. Amer. J. Roent. Rad. Ther. \& Nuch Med., 1953, 59, 272-293.

HITCHCOCK, F. A. Studies in vigor. V. The comparative activity of male and female albino rats. Amer. J. Physiol, 1925, 75, 205-210.

MANOSEVITZ, M., \& ROSTKOWSKI, J. R. Effects of neonatal irradiation on postnatal activity and elimination. Radiat. Res, 1966, 28, 701-707.

RUSSELL, L. B. Effects of radiation on mammalion prenatal development. In A. Hollaender (Ed.), Radiation Biology. Vol. II. New York: McGraw-Hill, 1954.

WINER, B. J. Statistical principles in experimental design. New York: McGraw-Hill, 1962.

Notes

1. This research was supported by the program Sciences Related to the Nervous System under NIMH Grant No. 5 TI MH 8394-02. 2. Current address: Department of Psychiatry, Box 2921, Duke Medical Center, Durham, N. C. 27706. 